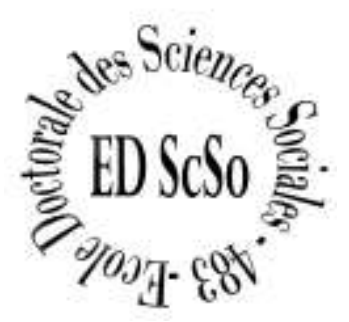

\title{
GLOBALIZATION AND GLOBAL HISTORY
}

\section{International Ph-D workshop Co-organised by}

The Doctoral School in Social Sciences ED 483 and the International PhD Study Program «IPP Transnationalization and Regionalization from the 18th Century to the Present » / Global and European Studies Institute / Frankreichzentrum from the University of Leipzig

Wednesday $13^{\text {th }}$ afternoon : Amphithéâtre Marc Bloch Thursday $14^{\text {th }}$ morning : Salle Elise Rivet

\section{Institut des Sciences de l'Homme de Lyon 14 Avenue Betherlot - 69007 Lyon}

Globalization has become a buzzword for all social and historical sciences. It nevertheless introduces new regimes of historicity and territoriality of societies. With concepts such as "world-society", or "global culture" or "global systems", Globalization theories have first and foremost focused upon the forms of globalization. Historical dynamics have nevertheless always shaped theoretical models of "globalization". The rise of a "Global history" aligning with the "Global Turn" in social sciences and humanities supposes a cross-examination of the epistemological and methodological outcomes. The relocation of social sciences on the "local" and the opposite, yet corresponding, recalling of the "global" by historical sciences unveil a series of crucial debates on the very nature of History (as a site of investigation and as a narrative) and the new ways of tackling historical issues. Because Globalization has become a conceptual problem and the source of epistemological discussions in almost all social sciences and humanities, this international workshop aims at questioning the changes (in scales, temporality) of historical research (or research on history) from different disciplinary viewpoints: sociology, history, anthropology and so on. The final purpose of this workshop is to offer a polylogical arena for researchers and $\mathrm{Ph}-\mathrm{D}$ candidates on topical theme - globalization.

\section{Opened to every Ph-D candidate, teachers and researchers}

Contact : Prof. Lionel Obadia, director of the doctoral school of Social Sciences of Lyon / SaintEtienne. Lionel.obadia@univ-lyon2.fr 


\section{Program}

\section{Wednesday $13^{\text {th }}$ February : Amphithéâtre Marc Bloch (ISH-Lyon)}

$14: 00$

Welcoming participants

$14: 15$

14: 30

Introduction to the doctoral training and presentation of the international workshop

15: 00

Matthias Middel (Leipzig) The regimes of territorialization in Global History

Lionel Obadia (Lyon) The meaning of Globalization and the idea of Global History in 15: 30

Anthropology: prospects and resistances

$16: 00$

Discussion on the papers and pause

Ulf Engel (Leipzig): Respacing Africa: Critical Junctures of Globalization $16: 30$

Philippe Bordes (Lyon): The Politics of Global Art History

$17: 00$-17: 15

Discussion on the papers

$17: 15-18: 00$

Global discussion

\section{Thursday 14th February : Salle Elise Rivet (ISH-Lyon)}

$10: 00$

Katja Naumann (Leipzig) World/ Global History in the US: the institutional contexts of its emergence and change

10 : 30

Herve Joly (Lyon): An Industrial Family facing up Globalization

11: 00 - 11: 30

Discussion on the papers and pause

11: 30

Kathleen Schluetter (Leipzig) The Transnationalization of Higher Education and $12: 00$

Research in France

Alain-Marc Rieu (Lyon) The Epistemology of Global studies and of Global History $12: 30$

Discussion on the papers and global discussion 